\title{
A mongol buddhizmus egy fó imája Öndör gegēn Janabajar, az első mongol egyházfő tollából, és az általa írt egyéb szertartásszövegek
}

A jelen cikk tárgyát képező, mongol szerző által, de szokás szerint tibeti nyelven íródott ima máig az egyik legfontosabb az amúgy fóként a tibeti buddhizmus szövegeit használó mongol buddhizmus mindennapi vallási gyakorlatában. ${ }^{1}$ Szerzője maga a mongol egyházfői tisztséget elsőként betöltő Luwsandambījalcan (T. blo-bzang dam-pa'i rgyal-mtshan)², a mongol buddhizmus máig legfontosabb alakja, akit tibeti neve helyett inkább Öndör gegēn Janabajar néven ismerhet a mongol történelemben, mongol buddhizmusban némiképpen jártas olvasó. Az Öndör gegēn, azaz „Őfényessége” maga az általa elsőként viselt cím, míg a Janabajar név a szanszkrit Jñānavajra ('a tudás vadzsrája') szó mongolos ejtésú alakja. Egyházfóként a bogdo vagy bogdo gegen (halha bogd gegēn, 'szent' / 'szent fényesség'), vagy az 5. dalai láma által adományozott jewcündamba xutagt (Mong. qutuүtu, T. rje-btsun dam-pa, 'szent nemes úr') rangot viselte, ilyen neveken találkozhatunk vele a szakirodalomban.

Jelen cikkben - Öndör gegēn szertartási szövegek terén folytatott munkásságának általánosabb ismertetését követóen - az általa îrt és a mongolok körében legfontosabbnak számító ima keletkezésének, hátterének, a mongol

1 Jelen cikk a Nemzeti Kutatási, Fejlesztési és Innovációs Hivatal - NKFIH - által támogatott projekt időszakában jött létre, de a projekt témájához nem szorosan kapcsolódó tárgyban (a támogató szerződés nyilvántartási száma PD 116108).

2 A nevek, terminusok megadásánál azok halha mongol alakját használom, kivéve néhány, a magyar nyelvú szakirodalomban már meghonosodott elnevezést, mint bogdo gegen, Abatáj kán stb. Ahol szükséges, feltüntettem a tibeti megfelelóket T. jelöléssel, illetve a szanszkrit megfelelőket Sz. jelöléssel, s néhány helyen a klasszikus mongol alakot Mong. jelöléssel. 
buddhizmus szertartási életében betöltött utóéletének bemutatásán túl fó célom a mongol buddhizmus legalapvetőbb imájának magyar nyelvú közreadása volt közérthető, könnyen olvasható, élvezhető fordításban, magyarázatokkal ellátva. Az imának a mongolság buddhizmusában betöltött jelentôs szerepe önmagában is megérdemel egy ismertetést magyarul, de a cikkben az Öndör gegēn által írt egyéb szertartásszövegekról adott összefoglalóhoz hasonló sem jelent meg még más nyelven sem. ${ }^{3}$ Annak rövid leírása, hogy e szövegeit ma a szertartásgyakorlatban pontosan hogyan használják, mely szertartások során, saját terepmunkán és kutatáson alapul - ez a jelen cikkbe csak röviden fért bele -, mint ahogy az is, hogy az elemzett imát milyen ajánlásokkal recitálják a mai szertartási életben, vagy a cikkben háttérként szereplő információk a mai mongol kolostorok mindennapos szertartásainak rendjéról. Az említett részek saját terepmunkán alapuló ismertetésén túl a szakirodalmi adatoknál minden helyen feltüntettem az adott forrást.

Janabajar (1635-1723), akit a tibeti mester, Tāranātha reinkarnációjának tekintettek, a tibeti buddhizmus Mongóliába történő bevezetésének kulcsfigurája volt. 1635-ben született a mai Öwörxangai megye Yesön Jüil járásában. Dzsingisz kán leszármazottjának tekintik az elsố mongol kolostort, az Erdene jūt megalapító Abatáj kán (halha Awtai xān) unokájaként. Ötéves korában a Širēt cagān nūr (Širēt cagān, azaz 'Trónusos fehér' tó) partján (a mai Öwörxangai megye Bürd járása) ültették trónusra. Első szerzetesi neve Išdorǰ (T. ye-shes rdo-rje) volt, későbbi felszentelési nevén vált ismertté Luwsandambījalcanként (T. blo-bzang bstanpa'i rgyal-mtshan (dpal bzangpo)). Nagy tibeti kolostoregyetemeken folytatott tanulmányai után az 5. dalai lámától és a 4. panchen lámától kapott beavatásokat. Az 5. dalai láma ismerte el ôt a tibeti mester, Tāranātha (mongolul J̌onon Darnad, 1575-1634), a Jonangpa rend utolsó nagy híres képviselője reinkarnációjaként, és ő adta neki 1651-ben a jewcündamba xutagt (T. rje-btsun dam-pa) címet is. Így vált a mongolok vallási és egyben politikai vezetôjévé.

3 Angol nyelvú disszertációm részeként olvasható több részlet is szövegeinek használatáról a szertartásrendben (Majer 2008). 
Több mongol kolostor alapítása kötődik a nevéhez. Ezek egyike a Barūn xürē, 'Nyugati kolostor' vagy Šanx(nī xürē) (másik neve Tüšēêt xanī xürē, tibeti neve Ribogeǰigandanšaddüblin), melyet 1647-ben alapított a mai Öwörxangai megye Xarxorin járásának területén. Legjelentősebb pedig a Ribogeǰigandanšaddüblin (T. ri-bo dge-rgyas dga'-ldan bshad-sgrub-gling) vagy Nomīn ix xürē, azaz 'A Tan nagy kolostora' néven ismert kolostor, melyet 1654-ben alapított a Xentī-hegységben, a mai Töw megye Möngönmor’t járása területén, és melyet Sar'dagīn xīd vagy Jün xürē, 'Keleti kolostor' néven is ismerünk, a fent említett és elóbb alapított Šanx vagy Barūn xürēhez, 'Nyugati kolostor'-hoz viszonyított elhelyezkedése miatt. Később, 1680-ban a halha-ojrát háborúk idején lerombolták, viszont ezt a kolostort tekintik a későbbi Ix xürē vagy Bogdīn xürē, a számos költözés után végül a mai Ulánbátor területén letelepedett kolostorfőváros elődjének. Az általa alapított egyéb kolostorok közül még kiemelkedik elvonulóhelye, meditációs kolostora, a Töwxön/Düwxan vagy Töwxön xīd (T. sgrub-khang, a $x \bar{\imath} d$ a kisebb kolostorok mongol elnevezése), melyet 1653-ban alapított (bár itt először csak meditációs barlang volt, szentély csak később épült). E kolostor eredeti, Öndör gegēn által adott neve E Wam gačillin (T. E-wam dga'-khyil-gling), a 'Módszer és Bölcsesség Öröm-kerekének (T. dga'khyil, Sz. ānanda-cakra, háromszínú egybecsavarodó lángból álló buddhista jelkép) kolostora'. ${ }^{4}$ Csodálatos helyen, a Xangai hegyvonulathoz tartozó Šiwēt-Ulān ūl nevü hegy tetején található (a helyszín 2004-ben az UNESCO világörökségi listájára is felkerült az Orxon-völgy részeként), Öwörxangai megye Bat-Ölzī járásában, csak mintegy 60 kilométerre a híres xarxorini Erdene zū kolostortól. Maga Janabajar többször töltött ott hosszabb-rövidebb időszakokat, tibeti tanulmányaival megszakítva, és az ojrát Galdan Bošigt serege elől is itt rejtőzködött el sikeresen az ojrát (nyugati) mongolok és a halhák közti háborúk idején, 1688-ban.

Kiváló szobrász és múvész volt, a mongol vagy másképpen Janabajar iskolának nevezett irányzat megalapítója a buddhista múvészet jónéhány ágában: főként bronz-, aranyozott vagy rézszobrai által, melyeket ma

\footnotetext{
4 A szerzőnek e kolostorról mint zarándokhelyről szóló cikkét lásd Majer 2012.
} 
néhány mongol kolostorban, illetve a Janabajar Képzőmúvészeti Múzeumban és a szintén ulánbátori Čoijin Lama Szentélymúzeumban ${ }^{5}$ ooriznek. Leghíresebb, a Töwxön kolostor magányában készített aranyozott szobrai például a Mahākāla-szobor (Maxgal, T. mgon-po), melyet ma a fentebb már említett Barūn xürē vagy Šanx(nī xürē) kolostorban őriznek; a ma az ulánbátori Gandan vagy Gandantegčenlin (T.: dga'-ldan thegs-chen-gling) fókolostorban található Vajradhara-szobor (Očirdar', T. rdo-rje 'dzin-pa); a 21 Tārā-szobor (Dar' ex, T. sgrol-ma); az 5 dhyāni buddha vagy meditációs buddha (yazgūrīn tawan burxan, T. mgon-po rigs-lnga) szobrai; és az Amitāyus-ábrázolás (Cewegmed, T. tshe-dpag-med). ${ }^{6}$

Janabajar a mongol írásrendszerek közül kettő, az 1686-ban a Töwxön meditációs kolostorban megalkotott, díszítő írásként használt Soyombo (Sz. svayambhū (jyoti), 'önmagától keletkezett', T. rang-byung) írás, melynek első jele fontos szimbólumként a mongol zászlót, ${ }^{7}$ valamint címert díszíti ma is ${ }^{8}$; illetve a fekvő négyszögletes írás vagy vízszintes pecsétírás (Xewtē dörwöly̌in, T. yig gru-bzhi) megalkotója volt. Mindkettő célja az volt, hogy speciális karaktereikkel ne csak a mongol nyelv, de a tibeti és szanszkrit nyelvek (a mongóliai buddhizmus szent nyelvei) minden hangját is le lehessen jegyezni. A két írás egyike sem került be a mindennapi használatba, inkább díszítőírásként alkalmazták, ma is láthatjuk például imamalmok vagy kolostori névtáblák feliratain.

Jelen cikk tárgyához szorosabban kapcsolódik, hogy nevéhez fúződik a sajátos mongol buddhizmus megteremtése, melyet a tibeti buddhizmusnak

5 Ez eredetileg Luwsanxaidaw-nak, a Čoiǰin lamként (T. chos-skyong bla-ma, 'Tanvédő láma') ismert állami jósnak a kolostoregyüttese volt, épületei túlélték az 1937-38-as kolostorrombolást. Ma múzeumként múködik.

6 Képzőmúvészeti munkásságába legteljesebb betekintést ad bőséges képanyaggal: Cültem 1982. Öndör gegēn örökségéről, beleértve múvészeti munkáit is, mongol nyelven lásd Teleki 2013.

7 A mongol zászló függőleges piros-kék-piros három sávja közül a bal oldalin található sárga színnel a soyombo jel.

8 A mongol címeren sötétkék korong közepén egy sárga színú szárnyas vágtató ló (ez a mongoloknál a szerencse, az életerô jelképe is hīmor vagy lündā, T. rlung-rta, 'szélló/szélparipa' néven) látható, azon, a lovas helyén a soyombo jelképpel. Ezt kör alakú sárga díszítókeret veszi körül, csúcsán hármas drágakôvel. A címer alsó részén szintén egy buddhista szimbólum, a Tankerék található. 
a speciális mongol szokásokhoz és körülményekhez igazításával formált különlegessé. A buddhizmusra jellemző volt ez a helyi istenségeket, szokásokat, szertartásokat beolvasztó, helyi kultúrákhoz alkalmazkodó képesség, Mongóliában pedig fóként Janabajar volt az, aki e helyi jellegzetességeket kialakította, rendszerbe foglalta, meghonosította. Ez többek között külsőségekben, mint a speciális mongol lámaruházat (része a hagyományos mongol köpönyeg, dēl, melynek hajtókája viszont a hagyományos mongol dēl hajtókájától eltéróen egyenes, nem ívelt), valamint jellegzetes recitálási módokban és dallamokban mutatkozik meg - a tibeti hangzástól eleve eltér a gyorsabb ének, a tibeti szövegek torzított mongolos ejtése is. A speciális szertartási rendszer is ekkor alakult ki: megjelentek jellegzetes, csak a mongol kolostorokban tartott mongol buddhista szertartások, a tibeti szertartások módosultak dallamukban, illetve általa és más mongol szerzetesek által szerzett új szövegek beiktatásával. A mongol buddhizmus e sajátságainak megơrzésére az ötvenéves elnyomást követő vallási újjáéledéskor nagy figyelmet fordítottak, így az általa bevezetett jellegzetességek napjainkban is élnek. ${ }^{9}$

\section{Az Öndör gegēn által szerzett szertartási szövegek és recitálási módok, hatása a szertartásrendre}

Janabajar számos olyan szöveget írt, melyeket a szertartások során napjainkban is használnak. Ezek közül az itt közölt imát (legismertebb nevén J̌inlaw cogzol, T. byin-rlabs mchog-stsol, 'a legkiválóbb áldás(t árasztó)') mindennap, másokat jelesebb ünnepek kapcsán recitálnak minden mongol kolostorban. Jelentós például az általa írt Ce daye sog / Ce taye sog (T. tshe-mtha' -yas-sogs, 'Végtelen élet', Cewegmed, T. tshe-dpag-med, Sz. Amitāyus szinonimájaként) címú ima - akad olyan kolostor, ahol ez is a mindennapi szövegek közé került be - és számos, a Cagān sar ('Fehér hónap', a holdújév kezdete) szertartásai során recitált szöveg. Ezek közé tartozik a Geleg dodgi (T. dge-legs 'dod-dgu'i, 'Szerencsekívánság') címú ima (amely

9 Az újjáélesztett mongol buddhizmus szertartási rendszeréről bővebben lásd Majer 2008. 
például a Gandan főkolostor Güngāčoilin dacan-jában, T. kun-dga' chosgling grwa-tshang, Güngāčoilin kolostoriskola, a mindennapi felolvasásoknak is része $\left.{ }^{10}\right)$. Szintén a Cagān sar szertartásai során szerepel az Umlai daye (T. om-las bgrang-yas) címú múve, ${ }^{11}$ melynek recitálására a 15 napos szertartássorozat 14. napján, az Öndör gegēn halálának évfordulójára megemlékező 'Dupla ima' (Dawxar yerōl) szertartás során kerül sor, eközben ajánlják fel a Cogčid (T. tshogs-mchod, 'áldozatok csoportja', étekszentelés, Sz. gaṇapūjā) áldozatot lagdor (T. lhag-gtor, 'maradék áldozati sütemény') nélkül. Érdekesség, hogy a Gandan kolostorban a szerzetesi közösség étele részeként kiosztott sütemények ezen alkalommal az Öndör gegēn által készített nyomóformákkal (xew) készülnek.

A holdújév időszaka során tartott 15 napos szertartások (a tavasz első hónapjának 1-15. napján) a Buddha által a tévtanítók (tersüd, T. log-par lta$b a)$ csodatételek bemutatásával történt legyőzéséről emlékeznek meg (ennek neve Čoinpürel jon a , T. chos-'phrul bco-lnga, '15 csoda') a négy nagy éves Buddha-ünnep (Burxan bagšĩn ix düicen ödrüd) egyikeként. E szertartások jelentősen eltérnek a tibeti szertartásrendtől. ${ }^{12}$ Mongóliában Öndör gegēn ideje óta a 15 nap során minden délután az úgynevezett Oroin yerōll (T. smon-lam, 'Kiváló ima'), Ix yerōl (T. smon-lam chen-po, 'Nagy ima') vagy Čoinpürel molom yerōl (T. chos-'phrul smon-lam, 'A csodatételek imái') szertartásokat tartják, az egykori kolostorfővárosban, az Ix xürēben bevezetett módon. Különböző szövegeket, mint például a '32 magasztalás/dicséret' (magtāl, T. bstod-pa) és a '6 ima' (jurgān yerōl, T. smon-lam drug) recitálnak kiemelkedôen szép dallammal e szertartások során. Az Ix yerō l szertartások

10 Šarjin (T. shar byung, szó szerint 'megjelenik/keletkezik'), a kolostoriskolák mindennapi szertartásának neve.

11 Byambā 2004: 8,00008. tétel.

12 A mongol buddhizmus kapcsolódó szertartásainak bővebb leírása itt elérhető: Majer 2008. A tibeti hagyományban a Monlam Dutsen (T. smon dus-chen/smon-lam dus-chen, 'Imaünnep') fesztivált tartják ebben az időszakban, mely holdújévkor - tibetiül Losar (T. lo-gsar, a holdújév első napja) - kezdődik, de ez 21 napig tart eltérő szertartásrenddel - a mongolok a Buddha csodatételeiről szóló megemlékezésre eltéró szertartásokat vezettek be. A tibeti hagyományban 15-én a Chonga chöchen (T. bco-lnga mchod-chen, a '15-ei nagy áldozat') fesztivál kerül megrendezésre, amit régen a Jokhang főszentély (T. jo-khang) körül rendeztek meg, a Barkor körúton (T. bar-khor, 'középső körút'), a dalai láma jelenlétében. 
a tibeti hagyomány 'Nagy ima' nevú szertartásaitól Öndör gegēn Janabajar hatására különböznek annyira. Ố adta az Ix yerōl szertartások szövegeinek és menetének rendjéhez (gorim, T. go-rim) a mantrarecitáció részt. Több szöveget, különösképpen a mantrarecitációk szövegét ő írta, és a dallamokat is ezekhez. Mindezek miatt az általa eszközölt változtatások miatt beszélünk az újévvel egybeeső szertartások kapcsán is az 'Öndör gegēn általi szertartási szabályokról' (Öndör gegēnī deg, T. sgrig, 'elrendezés, sorrend'). Természetesen Öndör gegēn újításai nemcsak ezen időszak szertartásaira hatottak, itt ezeket most csak azért részletezzük, mert említeni kívánt legismertebb szövegei ezek során szereplenek a mongol szertartásrendben, a mongol szertartásrend egyéb részleteinek és változtatásainak leírása nem képezi jelen cikk részét. Szólnunk kell viszont még egyenként a Cagān sar szertartásai során énekelt, általa szerzett mantrákról, melyek recitálására ( $m \bar{a} n$ ' tatax) naponta a vita lezajlása (coglomd bosox, T. tshogs-langs, szó szerint 'felemelkedni a gyülekezetben', mivel ilyenkor a vitában részt vevő szerzetesek helyükrôl felállva a szentély közepén vitáznak) után kerül sor, a szertartás vége felé. Ilyenkor egy-egy láma recitálja az adott napi mantrát padjára felállva, a többiek csak egy-egy ponton kapcsolódnak bele. Ez a mantrarecitáció a szertartás legfelemelőbb része. A tibeti kapcsolódó szertartásoknak nem része a mantrarecitáció, bár a mongol hagyomány bevezetését onnan eredeztetik, hogy a tibeti ünnepen az összegyúlt hívek a szentélyben mantrákat recitáltak (később ez a szokás megszakadt), és ennek nyomán alkotta meg ezeket Öndör gegēn. Az általa e célra írt mantraszövegek a következők: hoyor mān' (T. ma-n்i gnyis) az elsố napon, mān' um um (T. ma-n்i om om) a 2., 6. és 10. napon, mān' um ya (T. ma-ñi om ya) a 3., 7. és 11. napon, mān' ladār (T. ma-ñi la-tā-ri) a 4., 8. és 12. napon, mān' tügǰe dagnyid (T. ma-ni thugs-rje bdag-nyid) az 5., 9. és 13. napon, valamint a norow badma mān' (T. ma-ñi nor-bu padma) a 14. napon, melyet Öndör gegēn halálának évfordulójával egybeesve kiemelt alkalom lévén a fô elóénekes (ix unjad, T. dbu-mdzad) recitál. Ez a mantra a leghosszabb, éneklése 2-3 óra hosszat tart. 
A 15. napon a mān' patamǰad (T. maìi pha-thams-cad) kerül sorra. ${ }^{13}$ A mantrákat a 15 nap során a fô elóénekes (ix unzad), a másod-elóénekes (baga unjad) és az énekesek ( $g o l c ̌$, 'középen ülők') felváltva recitálják ( $m a \bar{n}$ ' tatax), de a 14. napit, a leghosszabbat szokás szerint a fó elóénekes, illetve a 15. napit a másod-elóénekes adja elő.

Szertartási szövegek írásán és ezeknek a szertartásrendbe történő beillesztésén, a szertartásrend újraformálásán kívül a szertartások dallamának újrakomponálásában, a mongol buddhizmusra jellemző sajátos recitálási módok megteremtésében is jelentős szerepe volt Öndör gegēnnek. A holdújévvel egybeesô 15 napos szertartások előtt az általában öt napig tartó évzáró szertartások legelsô napján (a tél utolsó hónapjának 26. napja) az éves áldozati tészták (balin vagy dorom, T. gtor-ma, Sz. bali) felszentelésekor, a Balin adislaga vagy Adislaga (T. byin-rlabs, 'felszentelés') nevú szertartáson például 108 cintányérütés hangzik el, nagyon lassú és dallamos módon - ezt az elemet is Öndör gegēn vezette be. Az éneklési, recitálási módok közül nevéhez füződik az úgynevezett 'régi dallam' ( $x \bar{u} c ̌ i n ~ y a n$, T. dbyangs, 'dallam'), míg az 'új dallam' (šin yan) a később az 5. jewcündamba xutagt által feltalált recitálás neve - mindettôt ma is használják egyes szertartásokon, vagy akár egy szertartáson belül bizonyos részeknél váltakozva. Számtalan szertartási szöveghez írt még Öndör gegēn dallamot, például a Daščǐraw san [T. bkra-shis char-'bebs(-kyi) bsang(s), 'Szerencse-esőtt hozó füstáldozat'] címú szöveghez, melyet D. Sugar és Š. Ad’šā, ${ }^{14}$ valamint J̌. Yerölt ${ }^{15}$ szerint a 4. panchen láma (Luwsan Čoiǰ J̌alcan, Loszang Csöki Gyalcen, T. blo-bzang chos-kyi rgyal-mtshan, 1570-1662) az ő kérésére írt a mongolok számára, azzal a céllal, hogy azok a nélkülözést elkerülhessék, szerencsés körülmények között élhessenek. A Daščǐraw san, mely a mongoloknál szinte az egyik legismertebb és leggyakrabban használt szöveg,

13 A mantrákat itt meg lehet hallgatni: http://bodhi.mn/?page_id=1510, http://bodhi.mn/?page_ id=1715 (Mongolīn burxanī šašnī xögjilīg demǰix san / Fund for Development of Mongolian Buddhism honlapja, letöltve 2016.02.13-án).Azoldalon közölt információk szerint a mantrákat énekli: a Dašgenpellin xīd lámája, Towū előénekes, B. Soronjonbold, a Barūn xürē lámája, J̌. Byambadorǰ, a Gandantegčenlin főkolostor előénekese, Lxagwasüren és J̌ambaldorǰ.

14 Sugar-Ad'šā 2004: 86-88.

15 Yerōlt 2016 (eredeti megjelenés helye ismeretlen). 
a 4. panchen láma által Öndör gegēn kérésére a mongolok jólétének elősegítésére írt három szöveg egyike, a másik kettő a mongol nép egészségéért írt rövid orvos-buddha szöveg [Baga Manal vagy Čogden/ Čogdon jalwa (manal), T. ? (rgyal-ba) sman-bla; S. Bhașajyaguru]; és az elhunytakat a halál után a Diwāj̆in paradicsomba (T. bde-ba-can, S. Sukhāvatī, a 'Nagy Boldogság Birodalma'), Amitābha buddha (Awid, T. 'od-dpag-med, 'a végtelen fény buddhája') tiszta földjére újjászületni segító Potid bawu yülǰigmā (T. 'pho-khrid dpa'-bo g-yul 'jug-ma) címú szöveg. Ez utóbbihoz Öndör gegēn magyarázatot is írt T. pan-chen chos-rgyan-gyis mdzad-pa'i 'pho-khrid-kyi kha-bskong, 'Kiegészító függelék a panchen láma, Chosrgyan által írt tudatátvitel útmutatóhoz' (mongol címén Bančin Čoiǰangīn joxioson Yegūtgelīn xötölbörīn nöxwör, 'Útmutató segédlet a panchen láma, Chos-rgyan által írt tudatátviteli útmutatóhoz') címmel. ${ }^{16}$

Öndör gegēn két fó tanítványa szintén a mongol buddhizmus fontos alakja volt: Jaya bandida Luwsanperenlei és Lamīn gegēn Luwsandanjanǰancan. Jaya paṇịta Luwsanperenlei (T. blo-bzang 'phrin-las, 1642-1715), akit a Xalxa Jaya bandid (halha Jaya paṇụita) vagy Jaya gegēn néven ismertek még, a láncolat első mongol újjászületése volt, egyben a mongol buddhizmus egyik legfontosabb alakja. Kolostora, a Jayaīn xürē a mai Arxangai megye Cecerleg nevú központjának területén állt - az 1937-38-as kolostorrombolásokat csak egy-két épülete élte túl, ma múzeumként múködik, egy külön megmaradt épületében pedig ma is szertartásokat tartanak. Lamīn gegēn Luwsandanjanǰancan (T. blo-bzang bstan-'dzin rgyal-mtshan, 16391704) egy másik neves mongol szent láma volt, az ô egykori kolostora, a Lamīn gegēnī xürē vagy Xamba (xutagt) nomon xanī xürē a mai Bayanxongor megye Erdenecogt járása területén volt. Hármójukat, mint a sárgasüveges buddhizmus (Gelukpa, mongol gelugwa vagy šarīn šašin, 'sárga vallás') mongóliai elterjesztőit a 'Tan három mécsese' néven nevezik együttesen. Ábrázolásokon gyakran szerepelnek Öndör gegēn két oldalán, hasonlóképpen, mint a Buddhát két fő tanítványával vagy Tsongkapát két fő tanítványával mutató képmások.

16 Byambā 2004: 7, 00007. tétel. 
Öndör gegēn Janabajarról mint egyházfőrool, munkásságáról, múveiről, képzőmúvészeti és egyéb tevékenyéségéről számtalan cikk és kiadvány áll rendelkezésre mongol nyelven is. ${ }^{17} \mathrm{~A}$ legújabbak egyike a születésének 380-ik évfordulójára 2015-ben Ulánbátorban tartott nemzetközi konferencia kötete. ${ }^{18}$

Haláláról Mongólia-szerte külön szertartással emlékeznek meg az első tavaszi holdhónap 14. napján, az 'Öndör gegēn nagy ünnepnapon' (Öndör gegēnī ix düicen ödör, T. dus-chen), a holdújévi 15 napig tartó szertartássorozat 14. napján, mellyel egybeesik, így aznap dupla szertartást tartva (Dawxar yerȫl, 'dupla áldás').

\section{„Időszerú ima” avagy „A legkiválóbb áldás(t árasztó)”}

Az alábbiakban magyar fordításban közreadott ima, más szertartási szövegekhez hasonlóan, a mongolok körében több néven ismert: röviden és köznapian Adistid címen ('Áldás', a szöveg kezdőszava, a T. byin-rlabs mongol megfelelője), a szövegkezdet első szavaiból álló mongolos ejtésú tibeti nevén J̌inlaw Cogjol formában (T. byin-rlabs mchog-stsol, 'A legkíválóbb áldást árasztó'), vagy eredeti tibeti címén Düitünji soldewként (T. dus-bstun-gyi gsol-’debs, 'Időszerú ima'). Az egyes szertartási szövegek recitálása általános, minden lény üdvéért és szenvedéstől való megszabadulásáért szóló áldásos hatásukon kívül különböző élethelyzetekben vagy különböző célok eléréséhez ajánlott: e szöveget a hívők számára ebben eligazítást adó rövid magyarázatok szerint a harmonikus életért, az akadályok eltávolításának céljával olvassák, valamint bármiféle válság, zúrzavar, harc, küzdelem, viszály lecsendesítésére, az öszhang és a békés állapot elérésére - mindez a szöveg tartalma és keletkezésének alább ismertetett háttere tükrében egyértelmú is lesz.

Az ima tibeti nyelven, hangsúlyos, kötött szótagszámú tibeti versben íródott: versszakainak minden sora kilenc szótagból áll. Mindezt természetesen a magyar fordítás nem adhatja vissza.

17 Például Sugar - Ad’šā 2004; Čoinxor et al. 1995.

18 Čulūn-Mönxǰargal 2015. 
A fordítás tibeti nyelvből, négy szövegváltozat összevetésével készült, négy modern mongol nyelvú fordítás áttekintése mellett (ezekről lásd alább). Rendelkezésre áll még két klasszikus mongol fordítás is. ${ }^{19} \mathrm{~A}$ tibeti szöveg fordításához a két legnagyobb mongol kolostor, a Gandan fókolostor és a Daščoilin kolostor mindennapi szertartási szövegeinek gyújteményében szereplő tibetit, a Lokesh Chandra általi szövegkiadást, ${ }^{20}$ illetve az Š. Bira által kiadott tibeti szöveget vetettem össze. ${ }^{21}$ Egy-egy mongol kolostor mindennapi recitálású szövegeinek száma (gorim, T. go-rim, 'sorrend', a szövegeknek a rectitálási sorrendben készült listáját jelenti) általában a kolostor méretétôl, szerzeteseinek számától függ, illetve természetesen a követett hagyományvonal szerint kerülhetnek bele az általánosan mindenhol recitáltak mellé különböző szövegek. A legtöbb helyen azonban a Gandan főkolostor 35 tételből álló napi szövegeinek gyújteményét követik - ettől lényegében kevésben tér el a Daščoilin kolostor szövegkönyve, mely 54 szövegből áll. A Daščoilin kolostor mindennapi szövegeit 2004-ben modern formában adták ki egy kötetben, ${ }^{22}$ tartalomjegyzékkel, ebben a szövegek címekkel vannak elkülönítve egymástól. Más Cogčin szöveggyújtemények, mint péládul a Gandan kolostoré tibeti sūtra (pothi) formában elérhetőek. Akisebb szentélyek a Gandan vagy a Daščoilin gyűjteményét használják, vagy egyes szövegekhez egy-egy széles körben elérhető kis imagyújteményt. ${ }^{23}$ A szöveg természetesen Öndör gegēn Janabajar összes múvei (sumbum, T. gsung-’bum) közt megtalálható, így az azt közreadó modern kiadványokban is elérhetô, például Lokesh Chandra kiadásában ${ }^{24}$ vagy újabban a Gurudeva

\footnotetext{
19 Bira 1995: 16-18, 20-22.

20 Lokesh Chandra 1982: folio 748-751 (az eredeti szöveg számozása szerint folio 100B-102A, a kötetben egy a különböző újjászületésekre vonatkozó életrajz, egy Öndör gegēn-életrajz, egy másik, kétnyelvú Öndör gegēn-életrajz, majd Öndör gegēn múvei szerepelnek egyben kiadva, a kéziratoldalak eszerint egyben is számozva vannak).

21 J̌ambal - Mönxsaixan 2004: 144-145, Gandan [kiadási dátum nélkül]: 297-300. azaz 136A-137B, Bira 1995: 15, 19.

22 J̌ambal-Mönxsaixan 2004.

23 $\mathrm{PhD}$ disszertációmban a mongol kolostorok szertartásrendjének ismertetésekor napi szertartásaikat is leírtam, ahol hozzáférhető volt, ott az egyes szentélyek eltérő szövegkönyveiben foglalt szövegcímek megadásával (Majer 2008).

24 Lokesh Chandra 1982: folio 748-751 (az eredeti szöveg számozása szerint folio 100B-102A).
} 
rinpoche ${ }^{25}$ által megjelentetett, R. Byambā általi sorozat első kötetében. ${ }^{26}$ Az MTA Keleti Gyújteményében is több példányban megtalálható a mú. ${ }^{27}$

A máig legfontosabb modern mongol fordítást, az ima rövid elemzését magyarázatokkal Š . Bira adta közre. ${ }^{28}$ A vékonyka kiadványnak része a szöveg Bira általi modern mongol fordítása, egy másik modern mongol fordítás, az eredeti tibeti szöveg, illetve két klasszikus mongol fordítás, valamint néhány oldalas ismertető és magyarázatok. Az ima népszerúségét mutatja, hogy nemcsak az egyes kolostorok imakönyveiben, például a lámák számára a mindennapi szertartási szövegeket akár mai kiadásban is elérhetővé tevő gyújteményekben szerepel (természetesen ezekben tibeti nyelven), hanem a mongol hívek számára kiadott sokféle tájékoztató füzet, kiadvány, könyv jó némelyike is közreadja egyéb fontos és lényegi imák mellett ennek is a fordítását (általában egyedüli mongol szerző által írt szövegként). Mivel a mongol buddhizmus egyházi nyelve ma is a tibeti, a szertartások, imák tibetiül folynak, az érdeklődő hívek számára különösen fontosak az efféle, a szövegeket saját nyelvükön is közreadó kiadványok (általában a szöveg kívülről történő megtanulását, recitálását számukra a tibeti nyelv ismerete nélkül is lehetővé tevő, cirill betúkkel lejegyzett mongolos ejtésú tibeti eredeti mellett).

A vers szerkezete a szertartási szövegek egy részére jellemző héttagú felosztást [(Mörgölīn) dolōn gišün, T. yan-lag bdun-pa] követi:

1. meghajlás vagy hódolattétel (mörgöx, T. phyag-'tshal-ba, Sz. vandana) - első 4 sor

2. áldozattétel (örgöl örgöx, T. mchod-pa phul-ba, Sz.pūjā) - 2 sor

3. a bűnök megbánása [(nüglē) naminčlax, T. bshags-pa]-1 sor

25 Belsô-mongóliai születésú láma, Tibetben és Nepálban tanult, nagy szerepe volt a mongol budhizmus újjáélesztésében, több kolostor újjáépítéséhez is hozzájárult. Később konfliktusba került a dalai lámával az általa betiltott Šügden (T. shugs-ldan) védőistenség tisztelete miatt.

26 Byambā 2003.

27 Orosz 2008-2009: Dus-bstun-gyi gsol-'debs 520.58.4, 536.17, 543.4, 592.38; Dus-bstun-gyi gsol-'debs Byin-rlabs mchog-stsol-ma 568.41; Byin rlabs mchog-stsol-ma 520.30, 543.4, 607.6.2; Byin-rlabs mchog-stsol-ma dang / Ma-nii'i ril sgrub-kyi cho-ga'i 'don-cha sogs 607.6 .

28 Bira 1995: p. 7-9. 
4. az erényes tettek iránti örvendezés [(buyan̄̄g) dagan bayasax, T. rjes-su yi-rang-ba] - 1 sor

5. a Tan terjedésének ösztönzése [duritgax, T. (chos-kyi-'khor-lo bskor-bar) bskul-ba] - 2 sor

6. (a szenvedésből való nem elmúlásért, azaz minél hosszabb ideig a Földön maradásért szóló) ima elmondása [jalbirax, T. (myangan-las mi-'da'-bar) gsol-ba (gdab-pa)] - 22 sor

7. az ezzel gyújtött erényeknek az összes lény megvilágosodásának céljára történő szentelése [joriulax, T. (dge-ba rdzogs byang-du) bsngo-ba] - utolsó 4 sor.

A hanyatló idő, ${ }^{29}$ mely a vers születésének időpontjára, de ugyanúgy napjainkra is vonatkozik, egy sötét korszak, melyben a buddhista szemlélet szerint a buddhista Tan csak kis mértékben van jelen, nem hatja azt át, így a tudatlanság következtében értelemszerúen a lények búnei, tévelygései, következésképp szenvedései is megsokasodnak, nagy nyomorúságba juttatva őket. Az ima pontos keltezését a kolofon nem adja meg, ${ }^{30}$ de vitathatatlanul a nyugati és keleti mongolok (ojrátok és halhák) közti sok áldozattal és szenvedéssel járó háborúk idején keletkezett, azzal a céllal, hogy a háborús nehéz időkből való kijutáshoz utat mutasson, annak a buddhista Tan, az ima erejével véget vessen, a viszálykodó mongolságot egyesítse, így békességhez juttassa. E tartalmi jellegzetessége miatt a mongolok még az Enx taiwan̄ jalbiral, azaz a 'Béke-ima' néven is emlegetik. ${ }^{31} \mathrm{D}$. Sugar és Š. Ad'šā például említi, hogy az 1939-es Xalxīn gol-i csata idején az emberek titkoban recitálták ezt a szöveget - nyilvánvalóan a béke elősegítéséért imádkozva

29 T. dus-ngan, 'rossz idő/nehéz idő', a mongol fordításokban cöwīn cag, 'hanyatlás kora/bajjal terhes idők' (ez a legmegfelelőbb terminológia), de előfordul a mū cag, 'rossz idő', és a munxag cag, 'sötét idő / a tudatlanság ideje' fordítás is.

30 Š. Bira szerint 1696-ban írhatta Öndör gegēn (Bira 1995: 3).

31 Mönx-Erdene 2008: 47. 
ezáltal. ${ }^{32} \mathrm{Az}$ ima tehát egy hanyatló korszak nehézségeit, jellegzetességeit alapul véve íródott. Van azonban egy sokkal mélyebb, kiterjedtebb jelentése is: mint minden tibeti ima, minden lény üdvére, megszabadulásának elősegítésre íródott, így minden sora örök érvényú. Minthogy jelen korszakunkban éppúgy időszerú, így talán nemcsak a mongolság üdvére szolgál, de napjaink magyar olvasóinak is reményt adhat központi, a tartós boldogságot, békét hívó gondolatával: „Minket, a hanyatló idők nagy sötétségével különösen teljes, / rossz sorsokban senyvedő lényeket óvjon a könyörületesség! / A rossz tettek nyomorúságának gyümölcsével teljes eme korszak / sokféle szenvedésének lángoló tüze majd ha teljesen kialszik, / a kölcsönös haragtól mentes, irgalmas szeretettel teljes szívbéli egyetértés / boldog tökéletessége, kérem, terjedjen el!"”.

A népszerú szöveget nemcsak a mindennapi szertartások részeként, de Mongóliában általában szinte bármilyen szertartási szöveg recitálása, például akár egy füstáldozat (san, t. bsangs) vagy egy szerencsehívó rituálé (dallaga, T. g-yang-'gug) után is olvassák.

A rövid kolofon keltezést szokás szerint ugyan nem, egyéb információkat azonban tartalmaz. Tanúsága szerint Öndör gegēn (a kolofonban 'Szent Híresség', T. dam-pa'i ming-can néven) egy Namǰil (T. rnam-rgyal) nevú tanítványa ösztönzésére írta, aki teljes felszentelésú szerzetes volt (gelen, T. dge-slong). Lejegyzője pedig Lodoi (T. blo-gros), a buddhista filozófia tudósa (rawǰamba, T. rab-'byams) volt. A kolofonban szerepló cím: dus-bstun-gyi gsol-'debs.

Az Öndör gegēn által tibeti nyelven írt szövegnek klasszikus mongol fordításai is készültek, ezek használata azonban a szertartási életben nem igazán terjedt el - ahogy a mongol nyelvú szertartások általában sem: a mongol buddhista egyház szertartási nyelve egy-egy kivételtől eltekintve a tibeti maradt. Inkább fordítástörténeti, irodalmi értékük van. Az egyik ilyen fordítás a Borǰgon gewš-ként (Borjigin nemzetségbeli T. dge-bshes, a tibeti buddhista filozófia doktora) is ismert Ištawxai gewš (Ištawxai Š., 1901-1972) fordítása,

32 Sugar-Ad’šā 2004: 78. 
mely Bira könyvében elérhető. ${ }^{33}$ Egy másik az egykor a Gandan főkolostor apáti rangját (xamba, T. mkhan-po) betöltő X. Gādan múve, aki 1981-1990 között töltötte be ezt a fó tisztséget. ${ }^{34}$ Bira könyvében az Ištawxai gewš által készített klasszikus mongol fordítás kéziratát és egy ismeretlen szerző által készített klasszikus mongol fordítás kéziratát is közreadja. ${ }^{35}$ Ahogy Bira írja, mindkét kézirat Š. Soninbayar, a Gandan tudós lámája tulajdonában van (vagy legalábbis Bira könyvének megjelentekor ott volt), és mindkettő Š. Soninbayar apai nagyapja, az egykori Secen xan aimaghoz tartozó Borjigin secen xošūban élt Togtoxučral által készített kézírásos másolat. Címük J̌ing-

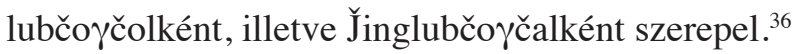

A modern mongol (halha), cirill betûs fordítások vagy a klasszikus mongol fordítások mai nyelvre történt átültetései, vagy a tibetiből készült fordítások. Ezek közül a legfontosabb Š. Bira fordítása (és a hozzáfúzött magyarázatok), melyhez könyvében közli a tibeti eredetit is, hozzátéve, hogy fordítása az általa szintén közölt két klasszikus mongol fordításra is támaszkodva készültt. ${ }^{37}$ Š. Bira fordításának mongol címadása a kétféle tibeti cím egymás utáni fordítása, a következóképpen: Cag lugā joxildūlsan jalbiral Adistadīn dēdīg xairlagč oršiwoi ('Az időnek megfeleltetett / A korral összhangban levő ima, a legkiválóbb áldást árasztó'). E fordítást gyakran adják közre újra a mai kiadványokban. ${ }^{38}$ Könyvében szerepel egy másik modern mongol fordítás is, ${ }^{39}$ egyszerúen J̌inlawčogjol címen, melynek eredetéról annyit említ, hogy B. Širendendew akadémikus magángyújteményéből való,

33 Bira 1995: 18. és 16. oldalak.

34 Bira könyvében csak említi ezt a fordítást (Bira 1995: 4). Byambā (Byambā 2004: 43) a szöveg két elérhetôségét is megadja: Xürelbātar 1992: 11 és Tüdew 1995: 283.

35 Bira 1995: 16 és 18, illetve a másik fordítás a 17., 20., 21., 22. oldalakon.

36 Byambā az Ištawxai és Gādan általi fordításokon kívül még Gelegjamc dōrombo (T. dge-legs rgya-mtsho mdo-rams-pa, 1869-193?) fordítását említi, az általa Gelegjamc fordításaként hivatkozott mú azonban egy Agwān Ešitüwden/Ištüwden (T. ngag-dbang ye-shes thub-bstan) által írt Öndör gegēn-életrajz Gelegjamc általi fordítása, mely az adott oldalon néhány mondatban említi csak a J̌inlaw cogjol imát (Kämpfe 1981: 352) - ezt Bira idézi is múvében (Bira 1995: 3).

37 Bira 1995: 7-9, illetve 10-13.

38 Például: Sugar - Ad’̌̌ā 2004: 80-81. A 78-80. oldalon az imához tartozó magyarázat nagy részét is Birától vették.

39 Bira 1995: 14. 
és Bira rendelkezésére Serēter, ${ }^{40}$ a Gandantegčenlin kolostor Dečingalaw szentélyének (Dečingalaw dacan vagy Düinxor dacan, T. bde-chen bskal-pa, dus-'khor grwa-tshang, 'Szerencsés kalpa / Kālacakra szentély') feje bocsátotta. A harmadik, gyakran használt mai mongol fordítást Ištawxai fordításaként emlegetik. Ezt több kiadványban is megtaláltam, ${ }^{41}$ eltéró címekkel: J̌inlawcogjolmā, Adistidīn manlaig öršōogč oršiw ('A legkíválóbb áldást árasztó') ${ }^{42}$, Caḡ̄g toxinūlagč jalbiral ${ }^{43}$ / Cagīn toxinūlax jalbiral ${ }^{44}$ ('Az idōnek megfelelő / A korral összhangban levő ima). Egy negyedikféle mai mongol fordítás is több kiadványban fellelhetô. Ezek egyike mellett ${ }^{45}$ egy rövid magyarázat is szerepel C. Mönx-Erdene, a fóvárosi Daščoilin kolostor (T. bkra-shis chos-gling, 'Tan szerencsés kolostora', a fóváros második legnagyobb kolostora, a Jün xürē, 'Keleti kolostor' nevet is viseli a régi kolostorfóváros keleti kolostorrészének örököseként) szerzetesi fóiskolája vezetőjének tollából..$^{46}$ Itt a Caḡ̄g towxinūlagč soyorxol talwixuin surgāl oršwoi (J̌inlaw cogcolmā) ['Az időnek megfeleltetett tanítás, kegyelemosztó' ('A legkiválóbb áldást árasztó’)] címmel olvashatjuk az imát mongol nyelven, a másik két azonos fordítást közreadó kiadvány ${ }^{47}$ az Adistedīn dēè̄ g xairlagč ex, illetve J̌anlaw cogjol (Adistidīn dēd̄̄ xairlagč ex) ('A legkíválóbb áldást árasztó anya') címmel közli.

Mint láthatjuk, a fentebb megadott mongol címeken kívül (melyeken a szertartási életben az imát említik) mai mongol nyelvre átültetett fordításai különböző címeket adnak az imának, mint például a tibeti szövegkezdet tükörfordítása, azaz Adistidīn dēē̄g hairlagč, 'A legkiválóbb áldást árasztó’, vagy más szavak használatával azonos jelentésben Adistidīn manlaig

40 R. Serēter, aki 2004-ben halt meg, magas rangú láma volt. A Gandan kolostor Kālacakra szentélyében a darxan gesgüi ('nemes rendfelügyelő') tiszteleti címet viselte.

41 Čoinxor et al. 1995: 70, Mongol unšlaga, urilgās 2006/2008: 17-18, Burxan̄̄ šašñ̄ jan üilīn garin awlaga I. 2005: 50.

42 Čoinxor et al. 1995: 70.

43 Mongol unšlaga, urilgās 2006/2008: 17-18.

44 Burxan̄̄ šašnī jan üilīn garīn awlaga I. 2005: 50.

45 Darambajar 2008: 48-49.

46 Mönx-Erdene 2008: 47.

47 Bayasgalan 1996: 62-63 (e kiadvány egy tibeti nyelvkönyvecske, gyakorlásképpen szerepel benne a tibeti szöveg az 53-56. oldalon, majd a könyv végén a mongol fordítás); és Cecgē 2005: 35-36. 
örš̄ōgč. Máshol az eredeti tibeti cím tükörfordításával Cag lugā joxildūlsan jalbiral ('Az idővel összhangban levő / Időszerú ima'), Cag lugā tārūlsan jalbiral ('Az időhöz illő / Időszerú ima') ${ }^{48}$ vagy Caḡ̄g toxinūlax / toxinūlagč jalbiral, Caḡ̄g towxinūlagč soyorxol talwixuin surgāl ('Az időnek megfeleltetett tanítás, kegyelemosztó') cím szerepel. Az eredeti tibeti cím mongolos ejtésú változatával is említik, mint Düidünǰi soldew ${ }^{49}$ vagy Düidün soldew. ${ }^{50}$

Az imának születtek magyarázatai is (T. 'grel-ba, kommentár, magyarázat), szintén tibeti nyelven. A magyarázatokkal jelen cikk szerzőjének nem nyílt módja foglalkozni, nem is áll rendelkezésére ilyen szöveg, ám a felhasznált szakirodalomban három magyarázatról is esik említés. ${ }^{51} \mathrm{Az}$ egyik Agwānxaidüw (T. ngag-dbang mkhas-grub, 1779-1838), az Ix xürē kolostorfôváros apátjának (xamba, T. mkhan-po) munkája T. byin-rlabs mchogstsol-ma'i 'grel-pa tshig-don rab-gsal zhes bya-ba bzhugs-so ('magyarázat a byin-rlabs mchog-stsol-ma címú múhöz, a szavak jelentését megvilágító') címmel. Byambā mongol fordításban is megadja a címet: Adistedīn dēdīg xairlagč̄̄n tailbar üg utḡ̄g mašid todorxoilogč xemēx oršwoi.$^{52}$ A másik magyarázatot Ganjūrwa nomon xan (T. dka'-'gyur-ba no-mon-han) készítette T. rje-btsun dam-pa'i zhal-nas gsungs-pa'i byin-rlabs mchog-stsol-ma'i 'grelba ('magyarázat a J̌ewcündamba által kinyilatkoztatott byin-rlabs mchogstsol-ma címú múhöz') címmel, mongol fordításban szintén Byambā által: J̌awjündambīn aildsan adistidīn dēdīg xairlagčīn tailbar xemēx.$^{53} \breve{S}$. Bira említi könyvében, hogy felhasználta a Ganjūrba nomon xān által az imához tibetiül írt rövid magyarázatot, melynek címét röviden mint $\mathrm{T}$. byin-rlabs mchog-stsol-ma'i 'grel-pa bzhugs-so ('magyarázat a byin-rlabs mchog-stsolma címú múhöz') adja meg. Hozzáteszi, hogy az általa használt hatoldalas kézirat Š. Soninbayar magántulajdonában van. ${ }^{54} \mathrm{~A}$ harmadik magyarázat

\footnotetext{
Čoinxor et al. 1995: 69.

Mönx-Erdene 2008: 47.

Čoinxor et al. 1995: 69.

51 Byambā 2004: 43 mindhárom magyarázatot említi; Bira 1995: 5; Sugar-Ad’šā 2004: 79.

52 Byambā 2004: 43.

53 Byambā 2004: 43. Byambā hivatkozza a 20 foliós szöveg elérhetőségét is: Tashigangpa 1974: K kötet.

54 Bira 1995: 5.
} 
pedig a Möröngīn vagy Delgermöröngīn xürē-beli (delgermöröni kolostor: a Delgermörön nevú folyójáról elnevezett Mörön a mai Xöwsgöl megye központja, egykor a Xotgoid axai beisīn xošū területe volt) Angi bagš-ként is ismert Cerenjaw / Luwsancerenjaw agramba [T. (blo-bzang) tshe-ring-skyabs sngags-rams-pa, 20. század] alkotása, címe T. byang-phyogs bskal lhag lha Yo-gi Janabajras nyam-thags 'gro-rnams-la skyes-bskur stsol-ba'i dus-bstun gsol'debs byin-rlabs mchog-stsol-ma'i brjod don-bsam 'phel nor-bu snang-ba'i thabs-su spos me'i snang-ba lta-bu'i brjod tho bkod-pa bzhugs-so ('Az északi terület magasrendú istenség jógija, Janabajar által írt, az elkínzott lényeknek ajándékot adományozó dus-bstun gsol-'debs byin-rlabs mchog-stsol-ma címú mú értelmét kívánságot beteljesítő drágakő fényének módján füstölő tüzének fényéhez hasonlóan elbeszélő'), Byambā általi mongol fordításban Xoid jügīn xuw' ülemǰ burxan Yoga Janabajar doroitson am'tan nugüdad beleg xairlaxīn

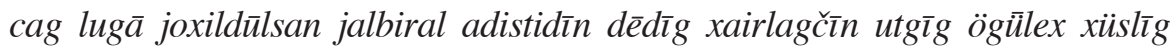
xangagč jindamani üjegdeld xü̈̌̄n gal met ögülex. Ugyanezt a magyarázatot említi D. Sugar és Š. Ad’šāa akik szerint, rövidebb címen említve csak mongol nyelven, J̌inlawcogjolīn utga sanānī ix čandman' erdn̄̄g üjegdexīn töd̄̄xön gereltülex xǚ̄̌n galīn gerel ('A J̌inlawcogjol értelmének nagy cintāmaṇi drágakövét világossá téve megvilágító füstölő tüzének fénye') címmel készült ez a kommentár. ${ }^{55}$

Bár az ima minden sora bővelkedik a buddhista szakszavakban (a tibeti buddhista panteon különböző alakjai, bűn, erény, a Tan kereke, létforgatag, lények, tudatlanság, sötétség, könyörületesség, hanyatló idők, rossz sorsok vagy létformák, a tettek gyümölcsei, nyomorúság, szenvedés, a három drágakő, a valóság mezeje, üresség, függésben való keletkezés, a létforgatagból való megszabadulás, Avalokiteśvara - a könyörületesség bódhiszattvája), lényege talán minden ide nem férő magyarázat és részletes lábjegyzetelés nélkül is értelmezhető lesz akár a buddhizmus eszméiben teljesen járatlan olvasó számára is, míg a folyóiratot már ismeró célközönség számára az alapfogalmak tisztázása, megjegyzetelése nem is szükséges, az élvezhetőség érdekében ettől el is tekintettem - tibetisták részére pedig az eredeti tibeti szöveg is szerepel a cikk végén.

55 Sugar-Ad’šā 2004: 79, a magyarázat tibeti eredeti címét nem is adja meg. 


\section{Időszerú ima}

\section{[A legkiválóbb áldás(t árasztó)]}

A legkiválóbb áldást osztó gyökérlámák,

a tökéletesség esőjét hullató védőistenségek, a békés és haragvó istenek, a minden akadályt elhárító égi istennők és tanvédők előtt

Test, Beszéd és Elme hármas útján nagy tisztelettel meghajolok.

A valóságos és a gondolattal teremtett áldozatok halma

az égboltot is beborítja, úgy áldozom.

A végtelen idők óta felhalmozott bűneimet megbánom, újra el nem követem. A közönséges és a nemes születésúek minden erényes tette nyomán én is örvendezem.

A mély és kiterjedt Tan kerekének megforgatását - a Tan átadását - szorgalmazom.

A végtelen létforgatag végezetéig, kérem, maradjon hát [a Tan] szilárdan jelen!

Az ezen erénnyel szimbolizált, de mérhetetlen erények halmát,

a három idő buddhái és összes tanítványai imája szerint arra szentelem:

Tisztuljon el minden lény tudatlanságának sötétsége!

A mindentudó bölcsesség fénye terjedjen el bennük!

Minket, a hanyatló idők nagy sötétségével különösen teljes, rossz sorsokban senyvedő lényeket óvjon a könyörületesség!

A rossz tettek nyomorúságának gyümölcsével teljes eme korszak sokféle szenvedésének lángoló tüze majd ha teljesen kialszik, a kölcsönös haragtól mentes, irgalmas szeretettel teljes szívbéli egyetértés boldog tökéletessége, kérem, terjedjen el! 
Megtéveszthetetlen Védelmező, ments meg, óvj meg!

Mérhetetlen Könyörületesség Kincsestára, Avalokiteśvara, tekints reánk, tekints le ránk!

Korábban tett erős fogadalmad ne feledd, emlékezz!

Gondolj ránk, figyelj ránk! Gyorsan védelmezz meg!

A győzedelmes Tan napfénye sugározzon a tíz irányba!

Minden lény állandó boldogságban, dicsőségben leledzzen!

Akadályozó bűneitôl megtisztulva az erények halmával teljes

mindentudás állapotát gyorsan, sebesen érje el!

A lámák és a Három Drágakő - Buddha, a Tan és a szerzetesrend - igazságának áldása,

a változástól mentes valóság mezeje - üresség - és a függésben

keletkezés csalhatatlan ereje,

és a mi hitünk és a Tanvédők kegyes tettei által

minden célunk kívánságunk szerint teljesedjék be!

A minden oltalmat egyesítő lámák áldása révén

az összes ideiglenes és végleges nyomorúság ahogy eltisztul,

a létforgatag és a belőle megszabadulás önmagától keletkezett jólétében,

a tökéletes fennköltségben való örvendezésnek az áldása áradjon szét!

Ezt az Idôszerü ima címü fohászt maga a Szent Híresség alkotta meg, tanítványának, a Rnam rgyal ('Tökéletesen gyózedelmes') nevü teljes felszentelésü szerzetesnek ösztönzésére. Papírra vetette Blo gros ('Bölcs'), a buddhista filozófia tudósa. 
A tibeti szöveg ${ }^{56}$

\section{Dus bstun gyi gsol 'debs bzhugs so/ ${ }^{57}$}

byin rlabs mchog stsol rtsa brgyud bla ma dang/

dngos grub char 'bebs yi dam zhi khro'i lha/

bar $\operatorname{gcod}^{58}$ kun sel mkha' 'gro chos bsrung la/

sgo gsum gus pa chen pos ${ }^{59}$ phyag 'tshal lo/

dngos bshams yid kyis sprul pa' $i^{60}$ mchod pa'i tshogs ${ }^{61} /$

nam mkha' ${ }^{62}$ khyab srid yongs su bkang ste 'bul/

thogs med $^{63}$ nas bsags sdig ltung bshags shing sdom/

skye 'phags ji snyed dge la rjes yi rang/

zab rgyas chos kyi 'khor lo bskor bar bskul' ${ }^{64}$

'khor mtha' srid du brtan bzhugs gsol ba 'debs/

'dis mtshon ma lus dge ba'i phung bo rnams/

dus gsum sras bcas rgyal bas ${ }^{65}$ yongs smon bzhin/

56 J̌ambal - Mönxsaixan 2004: 144-145; Gandan [kiadási dátum nélkül]: 297-300, azaz 136A-137B; Bira 1995: 15, 19; Lokesh Chandra 1982: folio 748-751 (az eredeti szöveg számozása szerint folio 100B-102A). A szöveget a Dašchoilin kolostor könyvéből teszem közzé, a másik három változatbeli eltéréseket lábjegyzetben a következőképpen jelölöm: 'Bira', 'Lokesh Chandra', illetve 'Gandan'.

57 Bira: Dus bstun gyi gsol 'debs byin rlabs mchog stsol ma bzhugs so/. Gandan: nincs külön cím, egyből elkezdődik a szöveg: byin rlabs mchog stsol. A Lokesh Chandra általi kiadásban nincs külön cím.

58 Bira: bcod.

59 Gandan: chen po.

60 Bira: yid sprul ba'i.

${ }^{61}$ Bira: mchod sprin tshogs.

62 Bira: nam mkha'i.

63 Gandan: thog med.

64 Lokesh Chandra: skul.

65 Bira: rgyal ba'i. 
'gro kun ma rig mun pa kun bsang ste/

kun mkhyen ye shes snang ba rgyas phyir bsngo/

cher snyigs mun chen lhag $\mathrm{par}^{66}$ gtebs $\mathrm{pa}^{67} \mathrm{yi} /$

bdag cag dus ngan 'gro la thugs rjes skyobs/

las ngan nyon mongs 'bras bu dus smin pa'i/ sna tshogs sdug bsngal me chen kun zhi nas/ phan tshun 'khon ${ }^{68}$ bral byams brtses yid mthun pa'i/ bde legs phun tshogs rgyas par mdzad du gsol/

skyobs shig skyobs shig bslu ba med pa'i mgon/ gzigs shig gzigs shig ${ }^{69}$ tshad med thugs rje'i gter/ ma g-yel ma g-yel sngon gyi thugs dam gnyan/ dgongs shing dgongs te myur ba nyid du ${ }^{70}$ skyobs/

rgyal bstan nyi 'od phyogs bcur rgyas pa dang/ 'gro kun bde skyid ${ }^{71}$ dpal la rtag spyod cing/ sgrib byang tshogs rdzogs kun mkhyen go 'phang la/ myur zhing ${ }^{72}$ myur ba nyid du reg ${ }^{73}$ gyur cig/

bla ma mchog gsum bden pa'i byin rlabs dang/ chos dbyings 'gyur med rten 'brel bslu med mthu/ bdag sogs mos pa chos bsrung 'phrin las kyis/ re 'bras ${ }^{74}$ mtha' dag yid bzhin 'grub par shog/

\footnotetext{
Bira: lhags par.

Bira: gtigs pa. Gandan: gtabs pa.

Bira, Gandan: khon.

Bira: gzigs shigs gzigs shigs. Gandan: gzigs shig zags shig.

Bira: nyed du.

Bira és Lokesh Chandra: bde skyed.

2 Gandan: myur shing.

73 Bira, Gandan: rig.

74 Bira: ri ’bras.
} 
skyabs kun 'dus pa bla ma'i byin rlabs kyis/

gnas skabs mthar thug rgud pa kun zhi nas/

srid dang zhi ba'i legs tshogs lhun grub pa'i/

phun tshogs ${ }^{75}$ dpal la rol ba' ${ }^{76}$ bkra shis shog//

ces pa 'di dus bstun gyi gsol 'debs 'di lta bu zhig gyis zhes ${ }^{77}$ slob bu rnam rgyal dge slong gis bskul ba' $i^{78}$ byed pas/ dam pa'i ming can gyi gyin bas ${ }^{79}$ bgyis pa' $i^{80}$ yi ge'i 'du byed rab 'byams ${ }^{81}$ blo gros kyis so//82

\section{Felhasznált elsődleges források}

A Gandan kolostor Cogčin szövegei [cím nélkül], hagyományos tibeti sūtra (pothi) formában nyomtatva, 411 oldal. Ulánbátor [szerkesztő és kiadási évszám nélkül]

J̌ambal, B. - Mönxsaixan, D. 2004, Dambajaw, Č. - Buyandelger, G. - Altanxǖ, C. (eds.), Jü̈n xürē Daščoilin xīd, Cogčin unšlagīn jereg tus amgalan garaxīn oron oršwoi, Tshogs-chen 'don-cha'i rim-pa phanbde 'byung-gnas bzhugs-so [A mindennapi szertartás szövegei, 'A bőség forrása']. Ulánbátor: Daščoilin kolostor

Bira: phun tshog.

Lokesh: rol ba'i.

Bira: zhis, Lokesh: 'os.

Lokesh: bas.

Bira: gyi na bas.

Bira: bgyi ba'i.

1 Lokesh: rab 'byams pa.

82 Bira és Lokesh: + dge bar gyur cig/. Ennek a szövegek végét záró általános szerencsekívánságnak felel meg a több mai mongol fordítás végén álló „um sain amgalan boltugai” kifejezés ('Legyen szerencse!'). 


\section{Felhasznált másodlagos szakirodalom}

Bayasgalan, A. 1996. Töwd xel exlen surax bičig [Kezdő tibeti nyelvkönyv]. Ulánbátor.

Bira, Š. 1995. Bogd J̌iwzündamba Janabajarīn joxioson „,Cag lugā joxildūlsan jalbiral adistadīn dēdīg xairlagč oršiwoi” " [A Bogd J̌iwzündamba Janabajar által írt „Időszerú ima, a legkíválóbb áldás árasztója”]. Ulánbátor: Nemzetközi Mongolisztikai Kutató Szövetség.

Burxan̄̄ šašnī jan üilīn garīn awlaga I. [Buddhista szertartások kézikönyve I.]. 2005. Ulánbátor: Mongol Buddhista Központ Gandantegčenlin kolostor - Öndör gegēn Janabajar Mongol Buddhista Egyetem. Byambā, R. 2004. Mongolčūdīn töwd xelēr tūrwisan mongol xelend orčūlsan nom jüin bürtgel, The Bibliographical Guide of Mongolian writers in the Tibetan Language and the Mongolian Translators. Vol. I. Ulánbátor.

Byambā, R. (ed.) 2003. Collected works of Jebzundampa khutukhts of khalkh. 1. rje btzun dam pa blo bzang bstan pa'i rgyal mtshan, II. rje btzun dam pa blo bzang bstan pa'i sgron me, II. rje btzun dam pa ye shes bstan pa'i nyi ma, Vol. 1. Ulánbátor.

Cültem, N. 1982. The Eminent Mongolian Sculptor - G. Zanabazar. Ulánbátor: Állami Könyvkiadó.

Čoinxor, J̌. - Norowsambū S. - Colmon, C. (eds.) 1995. Undur geghen Zanabazar / Öndör gegēn Janabajar. Ulánbátor.

Čulūn, S. - Mönxǰargal, B. (eds.) 2015. Öndör gegēn Janabajar. Am'dral, $\ddot{O} w$ [Öndör gegēn Janabajar élete és öröksége]. Ulánbátor.

Darambajar, B. 2008. Burxanı̄ šašnā dēdlen šïtexīn učir [Miért tiszteljük buddhista vallásunkat]. Ulánbátor: A Buddhista filozófia és valláskutatás ,Jün xürē” Főiskolája. 
Kämpfe, Hans-Rainer 1981. „Sayin Qubitan-u Süsüg-ün terge. Biographie des 1. rĴe bcun dam pa-Qutuqtu Öndür gegen (1635-1723), verfast von Nag gi dban் po 1839. Zwerte Folge.” Zentralasiatische Studien 15: $331-383$.

Xürelbātar, L. (ed.) 1992. Altan xürd [Arany kerék]. Ulánbátor.

Lokesh Chandra (ed.) 1982. Life and works of Jibcundampa I. [Śata-Pițaka Series Vol. 294.] New Delhi.

Lokesh Chandra 1961. Eminent Tibetan polymaths of Mongolia based on the work of Ye-shes-thabs-mkhas entitled Bla ma dam pa rnams kyi gsung 'bum kyi dkar chag gnyen 'bral dran gso'i me long. [Śata-Pițaka Series Vol. 16.] New Delhi: International Academy of Indian Culture.

Majer, Zsuzsa 2012. „Töwkhön, the Retreat of Öndör gegēn Janabajar as a Pilgrimage Site." The Silk Road 10: 107-116. [online változat: http://www.silk-road.com/newsletter/ vol10/SilkRoad_10_2012_majer.pdf]

Majer, Zsuzsa 2008. A Comparative Study of the Ceremonial Practice in Present-day Mongolian Monasteries. (PhD értekezés, Eötvös Loránd Tudományegyetem, Bölcsészettudományi Kar, Nyelvtudományi Doktori Iskola, Mongol Nyelvészet Doktori Program, Budapest)

Mongol unšlaga, urilgās [Mongol szertartásszövegekből]. 2006/2008. Ulánbátor: Mongol Buddhista Központ Gandantegčenlin kolostor.

Mönx-Erdene, C. 2008. „Caḡ̄g towxinūlagč jalbiral [Időszerú ima].” In: B. Darambajar (ed.) Burxan̄̄ šašnā dēdlen šütexīn učir [Miért tiszteljük buddhista vallásunkat]. Ulánbátor: A Buddhista filozófia és valláskutatás ,Jǖn xürē” Főiskolája, 47.

Orosz, Gergely 2008-2009. A Catalogue of the Tibetan Manuscripts and Block Prints in the Library of the Hungarian Academy of Sciences. Vol. 1-3. Budapest: Library of the Hungarian Academy of Sciences. 
Sugar, D. - Ad’šā, Š. 2004. Öndör gegēn [Öndör gegēn]. Ulánbátor

Tashigangpa, S. W. 1974, The Collected Works of Ngag-dbang-mkhas-grub. Delhi.

Teleki, Krisztina 2013. „Öndör gegēn Janabajarīn biyet bolon biyet bus öwīn jišē barimtūd [Öndör gegēn Janabajar tárgyi és szellemi öröksége]." Nomadic Heritage Studies Museum Nationale Mongoli XIII. facc. 36.: 304-321.

Tüdew, L. (ed.) 1995. Mongolīn Uran Joxiolīn Dējis [A mongol irodalom legjavából]. Ulánbátor.

\section{Felhasznált internetes forrás}

Yerōlt. J̌. Daščǐrewīn san joxiogdson tüxx [A Daščīrew san keletkezésének története]. az Öndör gegēn Janabajar Soyolīn San (Öndör gegēn Janabajar Cultural Fund) facebook oldalán (https://www.facebook. com/Өндөр-гэгээн-Занабазар-соёлын-сан-521895244656496/ ?fref=ts) [közzétéve 2016 február 23-án, eredeti megjelenés helye ismeretlen] 